\title{
Qadriya Sufis: Social Change in Society
}

Dr Syed Damsaz Ali Andrabi (Corresponding author)

Higher Education Jammu and Kashmir

Govt. Degree College Boys Pulwama, Kashmir

Tel: 96-2264-0951Ｅ-mail: damsaz.andrabi@gmail.com

Received: June 28, 2014 Accepted: August 28, 2014 Published: March 25, 2015

doi:10.5296/ijch.v2i1.7312 URL: http://dx.doi.org/10.5296/ijch.v2i1.7312

\begin{abstract}
Qadriya Sufis were the last to enter into the Valley of Kashmir. But they the first to reach far flung areas of Valley including district Pulwama. Not only religious activities were carried but equally new methods were introduced by them to change the economy of people. Involvement of people in different activities resulted in all-round progress irrespective of religion. With the result a concept of unity got developed in society. They acted as advisors of people and their interest in the mass welfare helped them a lot in communicating the message of peace and progress. In this hierarchy of education the Qadriya Sufi masters left no stone unturned to spread education to all corners of the Valley. Education was considered by them as a tool of change and highest service to humanity.
\end{abstract}

Keywords: Qadriya Sufis, Migration, Economy, Unity, Education

\section{Introduction}

Moving from Srinagar a number of prominent Qadriya Sufis spread to different parts of Valley. Rural areas were not fully exposed to the Sufi influence. Once they came in touch with the Sufis a dialogue with the Islamic thought and way of life also initiated in the interior areas. The Sufis spread their message in simple language and presented an exemplary way of living. The area of Pulwama (now a separate district) is centrally located in the Valley and is known for its clean water streams, magnificent trees and mighty mountains.Pulwama known for religious activities carried by different social reformers from time to time who came from outside and remained there permanently. Besides the ancient temples there are number of Shrines associated with different Sufis including the Qadriya Sufis. These Shrines which are there since times immemorial have shaped and reshaped cultural and moral values of people. Qadriya Sufis migrated to Pulwama from Srinagar district and remained there till the end. People were encouraged by Qadriya Sufis to work hard as much as they can as hard work is 
the key of success.

1.1. Syed Mohammad Sadiq ${ }^{1}$ Andrabi descendent of Syed Mir Mirak Andrabi (d1582.A.D) migrated from Malaratta Srinagar to Ratnipora and settled there permanently. Not imparted only religious education there, but according to Syed Shamsu'd-din, he also introduced some handicrafts such as Namda Sazi (Like a carpet) and embroidery work among the people for the upliftment of economic condition of the people. He preached that love for the person through whom Allah has bestowed his bounty on you becomes the cause of diminution in divine love. And it is obvious that Allah is very high and cares a lot as to what is sacred and inviolable. All hearts and souls derive sustenance and satisfaction from God and are at his mercy. He lightens the burden of load from their backs and does innumerable favours and bounties to his creatures. Because of bounties the whole area progressed much in the field of education. With the passage of time this tradition is still prevailing in the area. The rate of literacy is very high in the area. It showed good results by producing some prominent figures in the area. Syed departed in (1616.A.D) lies buried at Ratnipora ${ }^{2}$ in district Pulwama.

1.2. It was an era of darkness in the area of Puchal Pulwama. The life of common people was at its worst. The various clans were always at war with each other. No moral code of conduct existed in the society. Women folk were worst hit. It was around this time that Syed Qasim ${ }^{3}$ Ahmad Andrabi came and settled here. He was born in (1563.A.D) at Malaratta Srinagar in an affluent family of Andrabi Syeds. Being spiritually efficacious he succeeded in to reform the people and had a profound influence on their minds. Syed Qasims ancestors Syed Ahmad ${ }^{4}$ Andrabi and his son Syed Mohammad Andrabi migrated to Kashmir in the wake of missionary activities of Mir Syed Ali Hamdani ${ }^{5}$ during the rule of Sultan Qutubu'd-din (1373-89 A.D). They came and settled down permanently in the Valley of Kashmir. The Sultan was very much impressed by Syed Ahmad Andrabi, and constructed a Khanqah for him at Malaratta Srinagar, known by the name of Khanqahi Andrabia and granted him the Jagir of various areas. Syed Qasim ${ }^{6}$ Ahmad Andrabi, who devoted his whole life for the betterment of the people especially for the people of Village (Puchal) in district Pulwama. He changed socio-cultural life of people by his kind and compassionate nature. Syed Qasim ${ }^{7}$ Ahmad Andrabi was very popular among the people, not only for his religious activities, but also for his literary brilliance. He received his early Islamic education from his father. On the spiritual instructions from his father ${ }^{8}$, he spent ten years of his age on a hill at Awantipora (Pulwama ${ }^{9}$ ). From that place he migrated to Puchal ${ }^{10}$ (Pulwama) and settled down there. It is said that after a period of ten years in (1593.A.D) he came down from hill in a floody situation and there was only one boatman available at that time. The boatman refused to take him to the other side. According to tradition he ordered a big stone to take him to the adjacent area namely (Pazhil) Puchal. The stone floated on water and the great Syed reached the offshore. The stone is still identified by the people in the area of Puchal. It is believed that local population was generally influenced by his Karamats and adopted Islam. The tradition is that after reaching Puchal, he went in a house in search of fire, there was only a blind girl in the house, and after taking a little bit of fire from the house, the great Syed gifted her with the eyesight. The whole area ${ }^{11}$ of Puchal Pulwama was of Non-Muslims. Durga Nath Khar father of blind girl was the Jagirdar and leader of said community; he was the first to accept 
Islam at the hands of Syed. Afterwards all the residents accepted the Islam, and a new culture emerged there, and that influenced the adjacent areas also. As such people from far and wide were attracted and finally accepted Islam from the inner most recesses of their hearts. He made people understand the concept of oneness, and consequently a new culture emerged in which people could feel themselves free and safe. His religious activities became a turning point in the socio-religious and cultural ${ }^{12}$ activities of the locality. Such a social harmony had its impact on surrounding areas also. This Islamic brotherhood continued from generation to generation and people even at present remember the contribution of Syed ${ }^{13}$. According to local residents he also introduced some new areas of economic activity like weaving of Kashmiri Chadar (blanket) and embroidery with Golden thread (Zardoozi). Large numbers of people are still engaged with the profession of Zardoozi, which has really boosted and changed their economic setup. He also emphasized the Purdah system among the women folk. Turban was also introduced by him in the area. By this way Syed gave a new dimension to the socio-cultural and religious aspect of the area. There are certain Karamats related with the Syed in the area. The most important and famous are the four trees planted by the great Syed himself. The trees are almost more than four hundred years old, but are still in a good condition. The growth of the willow tree (Salix Alba) is downwards and bees are always around it. This means that the tree is having fragrance. The tree known by the name of Hujwiri inclines towards Kabba. The second one is the mulberry tree. This tree has fruits from summer to autumn. The rest two are the trees known as Brimig (Celatus Africana) in Kashmiri language. Another more attractive Karamat of Syed is spring bestowed to the people, known by the name of spring of Syed in the area. Its water also serves as the remedial treatment for all sorts of skin diseases. According to Mohammad-din Foaq the whole area of Puchal was the Jagir ${ }^{14}$ of Syed. He donated some portion of land among the Villagers. Plantation of almond tree was introduced by him, and some new agricultural activities were introduced in the area like the sowing of rice. Due to which agricultural ${ }^{15}$ sector progressed much in the area. Syed Qasim ${ }^{16}$ Ahmad Andrabi built several Mosques within the area, and also established several Maktabas for the purpose of Teaching of Quran and Hadith. His main aim was to propagate the teachings of Allah and Prophet. Some descendants ${ }^{17}$ of Syed left the Village of Puchal (Pulwama) and settled down at various places within and outside the Valley namely, Syed Sikander Andrabi at Trichal (Pulwama) and Syed Hassan Andrabi at Wandhama $^{18}$ (Ganderbal) Srinagar. Abdul Gafar at Gujrawan in Sialkot (Pakistan),Syed Mohi-ud-din Mohalla Farooq in Sialkot(Pakistan), Mohammad Amin Hardoo Mumbai (India), Ghulam Yasin and Nabeel Ahmad Riyadh (Arab) but at present they are in Islamabad Pakistan, Mir Mubarak Sialkot (Pakistan),Faqeer-Ullah in Sialkot (Pakistan),MirYousuf, Faiz Ali in Gujarat (Pakistan) Mir Akbar in Punjab etc. and followed the way of their ancestral profession. This migration also played a role in developing Kashmiri culture there. Not only people of the area were enlightened but equally people outside the Valley were benefited. The ancestral root of great Syed in Afghanistan (Andrab) gave a new dimension to dress, skills, language and literature of the area. The result was the emergence of a society, which though differing from old was rooted in the area. This is evident from the study of language, literature, and religious beliefs and social life of the area. Owing to the fusion of the old and new elements a new type of culture, manners, language, beliefs came into existence in the 
area. Syed Qasim Ahmad Andrabi breathed his last in the year (1631.A.D) at Puchal where his Shrine is located. Large numbers of people visit the Shrine of Syed Qasim Ahmad Andrabi at Puchal every day. Presently the annual Urs of the Syed is celebrated on 17th of April every year. His devotees offer rice and meat which are taken to the Shrine. Even the covering sheet of the grave of Syed is also presented by the devotees as homage to the great Syed.

1.3. Sheikh Ratan ${ }^{19}$ Kashmiri was a resident of Ratnipora Pulwama and disciple of Mir Ali Qadri (d.1660.A.D). Before his migration to Srinagar he acted as a teacher of the Maktaba in his own Village. The Maktaba of Ratan Kashmiri acted as a model in transforming the social structure of Village, because the major portion of Village was inhabited by the Non-Muslims. He never interfered in their religious matters, rather his philanthropic behaviour influenced upon people and they began study of Persian language. The doors of his Maktaba were open to all people. Along with religious education the students were also taught reading, writing and arithmetic. In the Maktaba on the very first day education was started by pronouncing the word Bismillah. The tradition of education was so strong here that in the present times it leads the way. According to census of (2001) it was rated as number one in the whole district. This influenced the surrounding areas also and they too are trying to compete and to acquire the knowledge. It was only through knowledge that the people were enlightened and newer ways were opened for them. He says that "acquire knowledge, because he who acquires it in the way of Allah, performs an act of piety, who speaks of it, praises the lord, who seeks it, adores God, who dispense instruction in it, bestows alms and who imparts it to suitable persons performs an act of devotion to God. Knowledge enables its possessor to distinguish what is forbidden from what is not, it lights the way to heaven, it is our friend in the desert, our society is solitude, our companion, when bereft of friend; it serves as an armour against our enemies". He left this world in (1680.A.D) and lies buried in Mohalla Sadar in Baghat Barzulla in Srinagar.

1.4. Syed Nur Shah ${ }^{20}$ Baghdadi arrived in the Valley from Baghdad in the year (1717-18.A.D) along with his spiritual preceptor Syed Mir Mohammad Hashim (d.1723.A.D). Both were ardent and strict followers of Qadriya order. On the instructions of his Murshid he settled in the Village of Gund Devsar Tral in district Pulwama. The area was dominated by Non-Muslims, and majority of them were Sikhs and the area was also having the rich literary tradition. Because of his piety and devotion the whole structure of the Village underwent many great changes. He demonstrated social philosophy of Islam to the residents of the Village. The doors of the teachings were open to all classes of people. Here the people noticed that all the inmates lived, slept and ate together. The holy book was accessible to every individual, high or low. A great advocate of the ethical values, he departed in (1753.A.D). His Shrine is situated at Gund Devsar in Tral $^{21}$ area of district Pulwama.

1.5. Syed Rukunu'd-din ${ }^{22}$ Baghdadi was great Sufi and soon after his arrival in Valley settled in the Village of Rang Mulla in district Pulwama. Having abandoned his worldly desires, he was devoted to piety and asceticism. He was not tied to his family, wife and children, not bound to his near and dear ones. He took abode in the deserted places and mountains and was averse to the company of worldly people. No wealth was stored by him, whatever he received 
in the evening distributed all to the needy in the morning. He breathed his last in (1758.A.D) and lies buried in the Village of Rang Mulla ${ }^{23}$ in Pulwama. At present the whole Village is engaged with the profession of gold. According to some gold smiths the art was introduced in the area by the Sufi. Before his arrival people were ignorant about the skill. But his arrival and permanent settlement in the area proved very beneficial for the people. With the result the area progressed much as compared to other areas of the district.

1.6. Syed Musa Baghdadi ${ }^{24}$, came to Kashmir from Baghdad (Iraq) and settled in the Village of Shadi Marg in district Pulwama. His date of arrival is not known. Syed Musa is said to have been extraordinarily pious and chaste. He kept fast continuously and would remain awake during the night. The fame of his piety and devotion went far and wide, and many became his followers. He is said to have a great herd of cattle, which were looked after by his followers. Once one of the followers was caught by a lion. Syed saw it and cried out to the lion, who released his follower at once. He then said to his follower that this had happened because one of you had done mischief. One of the followers confessed that he had picked up some corn somewhere and put it in his store. He remarked that you people were expected to maintain standards of morality far higher than those of common men. He breathed his last in (1800.A.D) and is entombed in the Village of Shadi Marg ${ }^{25}$ in district Pulwama.

1.7. Syed Sikander Andrabi ${ }^{26}$ was another great personality among the descendants of Syed Qasim Ahmad Andrabi (d.1631.A.D) who migrated from Puchal to Trichal ${ }^{27}$ (Pulwama) and remained there till the end. Syed Sikander Andrabi, because of his great eminence, became the preceptor of the people. Syed Sikander Andrabi had displayed many Karamats due to his extraordinary spiritual attainments. However he spent his energies mainly in preaching and teaching of Islam, and carried the profession of Islamic teaching there. He had no interest in material gains. His main aim was to propagate the teachings of Allah and Prophet (S.A.W). For this purpose a Maktaba was opened for Islamic education and guided the people to the path of Shariah. The said Maktaba is still functioning in the area. It is said that he was of the opinion that "God is light and those who are not able to perceive him, are like bats. The bats see nothing in the sunshine, only because of their own deficiency, and the sun cannot be blamed for it". He was also of the opinion that the real object (Allah) can be achieved through Zikr. When the seeker begins to find interest in Zikr, he becomes absorbed in it and separation from it causes great hardship and distress to him. Syed said that it is far better to first learn and acquire knowledge and then retire into seclusion. First kindle the lamp of Shariah then engage in divine worship and meditation. Allah expands the knowledge of the person, who acts upon it and opens the door of inspired knowledge, Ilm-i-Ludunni to him. He breathed his last in (1957.A.D) lies buried at Trichal in district Pulwama. However the urban and rural migration proved very fruitful for the common people. With the result economy and culture of people underwent many great changes.

1.8. In rural areas of Pulwama district the presence of Qadriya Sufi Shrines and Khanqahs is much higher than of any other Sufi Silsila. The life in the said areas revolves around the Qadriya Pirs. They remained in the company of people and acted as their advisors in their day today life. Social life beyond the family shows a close connection with the Sufi ways and a result of their influence over a long period of time. 
1.9. To understand the influence of Qadriyas in the Valley one has to see their overall presence in the Valley which suggest the prevailing dominant philosophy or ideology in the Valley. As a first indicator we look at the symbol and practices followed by people. A survey of the religious structures of Shrines and Khanqahs of Sufis gives some indication. Out of a total around one hundred and two Sufi Shrines around fifty two exclusively belong to Qadriyas and the rest are divided among Suhraward ${ }^{28}$, Kubravi ${ }^{29}{ }$ Naqshbandi $^{30}$ and Rishi ${ }^{31}$ orders. Similarly out of around forty eight Khanqahs around twenty eight belong to Qadriyas Sufis and rest belongs to all other orders.

1.10. Another significant feature in the Kashmir Valley is almost complete absence of Non-Muslim backward and Dalit groups. Most of the Non-Muslims belong to Brahmanical or other high caste groups. It signifies that the adoption of Islam was most enthusiastically done by the peasants, artisans and other low caste groups. Most of the Qadriya ${ }^{32}$ Sufis in urban areas were very close to artisan groups and lower strata of people. There are repeated references of the active role played by Sufis in encouraging people to take up new crafts. A quick survey of crafts and craftsmen of Kashmir we notice that quite a number of them were introduced in the Valley during the medieval period. The craftsmen of new crafts were also Kashmiris and were drawn from traditional artisans of prevalent crafts of wood, iron, gold, pottery leather work and metal work etc. New crafts introduced in the Valley, which are still practiced are, Zardoozi with Golden Thread (Tila work), Embroidery work on Shawls (Sozni work), Carpet Weaving (Qalin Bafs),Shawl Weavers (Shawl Bafs), Paper Machi (Zargars), Wood Carving (Najars) etc. Almost all the craftsmen express their allegiance to the popular religious practices which are identified with Sufis. Majority of them belong to Qadriya Silsila. The people belonging to various artisan centres and lower strata did not have much access to the socio-religious and cultural life in the towns. As in case of Bhakti, which found many eminent Saints among these groups, Sufism also appealed to them. The simplicity of the message of love towards God and uncomplicated devotional practices and access to a regular guide helped Qadriya Sufis in attracting people to Islamic religious fold became a gradual process. It in some ways offered these groups a hope and promise of a more egalitarian social existence. Syed Mohammad Mubarik Hussaini son of Jafar-al-Makki lists the following as the major causes ${ }^{33}$ of conversion, i) desire to get merit in this world, ii) fear of death and enslavement, iii) preachings of Muslims and, iv) bigotry of old faiths. In the case of Kashmir the Qadriyas did believe in preaching and for urban groups conversion seemed a better economic and social deal, through participating in new craft areas and a faith which promises social equality. In this context it is also pointed out"there was another reason for conversion through the process of acculturation particularly among the lower strata of society. Conversion through acculturation is a long process and can be distinguished from formal conversion-the latter might be called "conscious and formal conversion", while the former "conversion through the gradual and slow adoption of Islamic way of life" 34 . The similar process seems to have carried the Islam to the rural areas. Here the role of the Qadriya Sufis is very evident.

1.11. As noticed earlier they were the last to enter the Valley but first to reach the interior rural areas. In rural areas the presence of Qadriya Sufi Shrines is much higher than of any 
other Sufi denomination (in Pulwama ${ }^{35}$ six out of nine, in Baramulla ${ }^{36}$ five out of ten, Budgam $^{37}$ three out of four, Kupwara ${ }^{38}$ one out of two and only in Anantnag ${ }^{39}$ Rishi order has four out of six). Adoption of Islam by the Gujars the most prominent tribe in the Valley shows the trend as elsewhere in the case of tribes, the whole tribe of the region seems to have adopted the Islam. The life in the rural areas revolves around the Pirs most of who belong to Qadriya Silsila. They are consulted and provide guidance on all major decisions of the social and economic life of people. The efforts of the Sufi Saints have influenced the society in all diverse aspects. In spite of having an elaborate code of rituals and ceremonies with regard to birth, marriage and other day to day engagements Qadriya Pirs are consulted by the common masses on important occasions. In Kashmir every family is having a Pir. His consent and blessings are sought before any work, like marriage, building a house, giving names to children etc. In most cases the Muslims as well as Non- Muslims both have faith in the Shrines and the Pirs. For example for childless parents it was and still is customary to visit Shrines, call off a Pir and to keep fasts in order that they might be blessed with children. This is obvious and clear that the age old tradition of having a Pir and trust in Shrines played a larger part in the social life of people and continues even at present. Even the eleventh (popular Qadriya tradition) of every month of Islamic calendar is still celebrated by all the Kashmiris to fulfill their wishes as per the instructions they received from Pir and on this very particular day the people are invited and they used to sit together to recite the verses of Quran. At times attempts were made to wean away people from the mystic influence. The more orthodox followers of Islam organized under various organizations have tried to oppose the practices followed by the people under the Sufi ways of practicing Islam, terming it un-Islamic, but the influence and belief of people is deep enough.

1.12. Though the religion of Majority of people was Islam still a group of people raised their voice against the prevalent religious practices under the leadership of Mohammad Hussain a resident of Srinagar during the reign of Maharaja Ranbir Singh during(1857-1885.A.D). He tried his best to preach the Wahabi doctrines in Kashmir. His main opposition was against the profession of Pir Muridi, "superstitious rituals" and more importantly against the worship of Asthans (Shrines). But the opposition to his ideas was so strong that Maharaja was forced to give an order for Hussain's expulsion from the state. Later on in early twenties the Wahabis founded the Anjuman-i-Ahli Hadith, which came in the light under the leadership and guidance of Maulvi Ghulam Nabi Mubaraki and Maulvi Nuru'd-din. They confined themselves to the text of the Quran and Hadith and relied upon individual judgment for their interpretation. They denounced the worship of Pirs and advocated the abolition of anti-Islamic practices among the Muslims and it is very interesting that Wahabis and any another group of this thought is at present dubbed as Kutas (un-believers) by the majority of Kashmiri people. Even at present there are groups who criticize these practices in the Valley but they are keeping low and are not in a position to raise their voice against the Shrine. They too were against the Pirs and Shrine culture prevailing in the Valley, but their influence mainly remained confined only to some far flung areas of Valley. No doubt their struggle was against the people who have their faith in Pirs and Asthans (Shrines). The Shrines of Srinagar are under Wakf Board run by the state government and Village Shrines are under Village level committees. Some efforts were made to utilize the offerings for educational purpose. Islamic 


\section{Macrothink

University was established and also numbers of schools were opened and were kept under the special care of Wakf Board. The huge income received by Village Shrines is not utilized properly. If the money will be spent on opening of institutions the position would have been entirely different. So there is a dire need of reformation of Kashmiri society, so that the offerings may be used for development for which the charity boxes were meant for. This was the only reason that long back the guide line was prescribed by the great Qadriya Sufis who used to donate the offerings among the needy people, but unfortunately we all have not followed right path they have shown to us. Their attitude was based on sympathy and consideration. Their standard of moral values became an example to all Kashmiris in the diverse aspects of the social life. By virtue of these Sufis Kashmir Valley came under newer influences in the spheres of religion, culture, economy and art. Sufis of the order worked wholeheartedly to spread the message of unity far and wide in the Valley of Kashmir. They were well versed with the Persian language and literature. By this way they rendered great services to the Persian language. They were kept in high regard and esteem by the people for their religious and literary activities.

\subsection{Conclusion}

Qadriya Sufis encouraged and changed the educational system in the Valley. More and more emphasis was laid by them upon the education of every one especially the females. By virtue of Qadriya Sufis the position of women got completely changed in the Valley. Learning has been defined by them as the highest attainment of humanity, a way leading to right conduct and cultivation of virtue. But learning without putting it into practical use would be meaningless, teaching and imparting knowledge is considered to be the noblest occupation. Qadriya Sufis succeeded in changing the total outlook of Kashmiri society .In general people were influenced and visited their Shrines irrespective of religion. The devotees irrespective of their economic status bring food particularly Tahar and Qahwa to the Shrine daily. One may watch the beggars the poor and the rich men and women share the same food. In concluding remarks their long lasting impact can be realized:

1) Religious toleration.

2) Change in economy

3) Restoration of peace in society.

4) Concept of unity developed.

\section{Notes and References:}

1. Gamgeen, S, Genealogical Table of Andrabi Syeds, Srinagar, 1985,pp.10-11.

2. Ratnipora is located on north east of Pulwama town in Jhelum Valley plain.

3. Hussain Mohammad Qadri, Fatuhati Qadriya, Mss. pp. 9, Research library

University of Kashmir.

4. Gamgeen, S, Genealogical Table of Andrabi Syeds, Srinagar, 1985, pp. 1-2. 
5. Qadri Mohd. S. S, Majmul-Al-Buldan, urdu. trans. vol. i, Srinagar, 2005,pp. 108-109.

6. Rafiqi A. Q, Sufism in Kashmir, Srinagar,1976, pp. 54-55.

7. His father Syed Mir Mirak Andrabi (d.1582.A.D) was the first Andrabi in the Valley of Kashmir who became the follower of Qadriya Sufi order. The Sufi order was introduced by Syed Nimatullah Shah Qadri in the Valley of Kashmir during the rule of Chaks (1561-1586.A.D) .With the passage of time all his descendants became the followers of the Qadriya Sufi order.

8. Miskin Mohiu'd-din, Tarikhi Kabir, Srinagar, 1905, pp. 31-33.

9. Pulwama district came into being in the year 1979.A.D. The district is situated in the north of Srinagar at a distance of $32 \mathrm{Kms}$.

10. Village of Puchal is situated towards east of Pulwama and is almost $8 \mathrm{Kms}$ away from Pulwama town. The original name of Village actually was (Pazhil) which means to respect and to serve the guests and a new name, Puchal to the Village was given by the Syed.

11. Gamgeen, Shamsu'd-din, Nazneen Gamgeen, Srinagar, 1985, pp. 151-51.

12. Ahmad, Nabi, Zikri Saadati Andrabia, Srinagar, 1999, pp. 22-23.

13. Miskin Mohiu'd-din, Tarikhi Kabir, Srinagar, 1905, pp. 52-53.

14. Foaq Mohammad-din, Tarikhi Aqwami Kashmir, Srinagar, vol. I. 1911,pp.142.

15. Ahmad Syed, Tohfa Syed, Mss, pp. 3-4,Research library University of Kashmir.

16. Ahmad Syed, Tohfa Syed, Mss, pp. 3-4,Research library University of Kashmir.

17. Gagmen, S., Genealogical Table of Andrabi Syeds, Srinagar, 1985,pp. 31-32-35-36.

18. Wandhama is located on the North West side of Ganderbal district, almost 7-kms. from district headquarter. Ganderbal district lies at a distance of $20 \mathrm{Kms}$. from Srinagar district and is situated on the banks of river Sindh. The district which is flanked by district Baramulla on the west, district Srinagar on the south, newly created district Bandipora on the north-west, and district Anantnag on the south and Kargil on the east.

19. Miskin Mohiu'd-din, Tarikhi Kabir,Srinagar, 1905, pp. 208.

20. Hussain Mohammad, Fatuhati Qadriya,Mss. pp. 214, Research library University of Kashmir.

21. Tral town is located in north-east, of Pulwama town in greater sub Himalayan region.

22. Dara Shukoh, Sakinatul Auliya, urdu trans.by Maqbool Beigh, Delhi,1971, pp. 110.

23. Rang Mulla, is situated to the South of Pulwama town at a distance of five Kms.

24. Hassan Peer, Tazkira Auliya Kashmir,Srinagar, 1998, pp. 45.

25. Shadi Marg is situated to the South West of Pulwama town at a distance of ten Kms. 


\section{Macrothink}

26. Gamgeen, S, Genealogical Table of Andrabi Syeds, Srinagar, 1985, pp. 32.

27. Trichal is situated to the South of Pulwama town at a distance of four Kms.

28. Pandit Amin , Tarikhi Kashmir, Srinagar,1984, pp. 113.

29. Nuri Abdul Wahab, Fatuhati Kubriya, Mss,P.79, Research library University of Srinagar Kashmir.

30. John Subhan A, Sufism its Saints and Shrines, New Delhi 1999, P.187.

31. Ahmad Sheikh, Alamdar Kashmir, Srinagar, 1997, pp. 42, 194.

32. Qadri Hussain Mohd, Fatuhati Qadriya, Mss, pp.207-208, Research library University of Srinagar Kashmir.

33. S.Inayat A. Zaidi and Sunita Zaidi,Conversion to Islam and Formation of Castes in Medieval Rajasthan”in Art and Culture, ed. A. Jan Qaisar and S. P. Varma, Delhi, 1993, pp. $29 \&$ fn 22.

34. S. Inayat. A. Zaidi, Ibid, pp. 29.

35. Pulwama district came into being in the year 1979.A.D. The district is situated in the north of Srinagar at a distance of $32 \mathrm{Kms}$.

36. Baramulla is almost $52 \mathrm{Kms}$ from Srinagar and is surrounded in east by Kupwara.

37. A name of the District headquarter. It is situated in the North West of Srinagar city at a distance of $10 \mathrm{Kms}$.

38. Kupwara district came into being in the year 1979 A.D. It is $90 \mathrm{Kms}$ from Srinagar in the east and south lie Baramulla in the west and north there is LOC which separates it from Muzaffarabad Pakistan.

39. The history of district dates back to the times of Dogra rule when there were only two districts namely Anantnag including Srinagar and Baramulla were part of Kashmir. One has to cover a distance of $55 \mathrm{Kms}$. from Srinagar to reach Anantnag .It is bounded by Srinagar district in the north, Pulwama district in the northwest and Kargil district in the north.

\section{Copyright Disclaimer}

Copyright for this article is retained by the author(s), with first publication rights granted to the journal.

This is an open-access article distributed under the terms and conditions of the Creative Commons Attribution license (http://creativecommons.org/licenses/by/3.0/). 